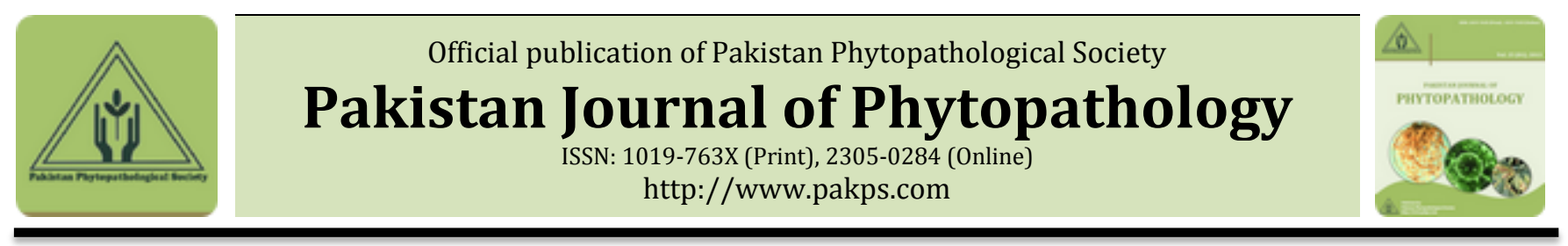

\title{
MANAGEMENT OF TOMATO LEAF CURL VIRUS THROUGH NON-CHEMICALS IN RELATION TO ENVIRONMENTAL FACTORS
}

\author{
aSaneela Arooj, aYasir Iftikhar, bMuhammad Kamran, cMuhammad I. Ullah, dMustansar Mubeen*, \\ eQaiser Shakeel, a Naila Zeerak, arram Bilqees \\ a Department of Plant Pathology, University College of Agriculture, University of Sargodha, Sargodha-40100, Pakistan. \\ bPlant Pathology Section, Plant Pathology Research Institute, Faisalabad-38000, Pakistan. \\ 'Department of Entomology, University College of Agriculture, University of Sargodha, Sargodha-40100, Pakistan. \\ ${ }^{d}$ State Key Laboratory of Agricultural Microbiology and Key Laboratory of Plant Pathology of Hubei Province, Huazhong \\ Agricultural University, Wuhan-430070, China. \\ eDepartment of Plant Pathology, University College of Agriculture and Environmental Sciences, The Islamia University of \\ Bahawalpur, Bahawalpur-63100, Pakistan.
}

\section{A B S T R A C T}

Tomato leaf curl virus (TLCV) is one of the most devastating and widely distributed viruses in the tomato crop, transmitted through whitefly in nature. Disease incidence and severity of TLCV were monitored on four tomato varieties/lines. Tomato leaf curl disease was managed through three non-chemical treatments viz., compost, nutrient enrich compost and multi-nutrients. The incidence of TLCV was found in the range of $57 \%$ to $70 \%$. Among all the tomato varieties/lines, VRI-49 was moderately resistant, Nagina and Money Maker were susceptible, and VRI-20 was found to be highly susceptible against TLCV. Compost $(44.02 \pm 3.26 \mathrm{c})$ was the most effective way to suppress the progression of disease severity. Environmental factors (Max. and Min. temperatures, Relative humidity and Rainfall) showed significant correlation with disease development. Treatments were able to suppress the disease development even in the presence of favorable environmental conditions. The increase in relative humidity increased the disease progression significantly.

Keywords: TLCV, Disease progression, Tomato, Non-chemicals and environment

\section{INTRODUCTION}

Vegetables are inevitable for human's diet and tomato crop gain importance because it's abundant use in everyday life. Like other crops tomato is also under the attack of many diseases caused by different pathogens. Among them, viral diseases are major constraints in tomato production (Chavan et al., 2015). Characteristic symptoms of tomato viruses are stunting, crinkling, small fruits or no fruits. Die back of infected plants has been found in severe cases (Raj et al., 2005). Tomato leaf curl virus (TLCV) is one of the most devastating viruses that causes heavy losses in yield of tomato crop around the globe. TLCV was firstly reported in the 1980s in Sudan and is

* Corresponding Author:

Email: mustansar01@yahoo.com

(C) 2017 Pak. J. Phytopathol. All rights reserved. transmitted through whitefly (Bemesia tabaci) as insect vector in nature (Sugano et al., 2011). It is a circular single stranded DNA Geminivirus belongs to family Geminiviridae (Gottlieb et al., 2010). Preliminary studies regarding incidence, transmission, detection and characterization have been carried out in the different part of the world (Rybicki, 2015). Different viral diseases in Pakistan are; Tomato leaf curl virus (TLCV), Tomato mosaic virus (ToMV), Potato virus X (PVX), Cucumber mosaic virus (CMV), Tomato yellow top virus (TYTV), Tomato spotted wilt virus (TSWV) and Tomato ring spot virus (TRSV) (Mughal, 1985). During a survey in tomato fields of Hyderabad district, Sindh, Pakistan, 68\% of tomato fields were infected with different kinds of viruses. The mean incidence of different viral diseases of winter tomato; Tomato mosaic virus (ToMV) 34.38\%, CMV 12.92\%, TLCV 15.08\%, and TYTV 8.26\% were 
recorded on the basis of symptoms in Malakand agency (Hassan et al., 1993). The epidemics of TLCV in relation to increase in whitefly population on tomato has been reported (Maluta et al., 2014). Chemicals and botanicals/plant extracts have been used to control the insect vector during the management of plant viruses. Moreover, non-chemical approaches are also the eco-friendly. Non-chemical approaches including micronutrients and botanicals have been used to manage plant virus (Ali et al., 2014). The incidence of TLCV can be reduced through different chemicals and using certain practices in the field (Chakraborty et al., 2003). Another approach practiced in protected culture is Ultraviolet absorbing plastic films; have presented good results (Antignus et al., 2001). Another approach named as Rouging was also highly recommended and plants exhibiting early symptoms can be detached to decrease the inoculation source inside the fields (Polston et al., 2007). Non-chemical approaches to control the diseases are not only ecofriendly but also the need of time. Continual prevalence of viral diseases is considered to be the major cause of low tomato production. There is the scarcity of information regarding incidence and

$$
\text { Percent Disease Incidence (PDI) }=\frac{\text { Number of diseased plants }}{\text { Total number of plants examined }} \times 100
$$

Disease severity was calculated according to Lapidot et al., (2001) the disease rating scale with slight modifications as follows:

\begin{tabular}{lll}
\hline Rating scale & Severity Range & Response \\
\hline 0 & No symptoms & Highly Resistant (HR) \\
\hline 1 & mild curling (25\% leaves) & Resistant (R) \\
\hline 2 & Curling, puckering (26-50 \% leaves). & Moderately Resistant (MR) \\
\hline 3 & Curling, puckering of 51-75\% leaves & Susceptible (S) \\
\hline 4 & $\begin{array}{l}\text { Severe stunting and yellowing, pronounced leaf cupping and } \\
\text { curling; growth of plant stopped. }\end{array}$ & Highly Susceptible (HS) \\
\hline
\end{tabular}

Nutritional Management: Four treatments;

$\mathrm{T} 1=$ Control (Nothing applied except water),

$\mathrm{T} 2=$ Compost,

T3= Nutrient Enriched Compost (NEC). (Applied in form of granules in the soil near the base of plants),

$\mathrm{T} 4=2.5 \%$ Multi-nutrients. Multi-nutrients were applied as the foliar spray.

Meteorological data (minimum and maximum temperatures, rainfall and relative humidity for the whole period of trial (from sowing till harvesting of the crop) was collected from the weather station of In-service agriculture training institute. The trial was carried out in a randomized complete block design (RCBD) with three replications. The collected data was subjected to statistical analysis using " $R$ " software for Windows". management of TLCV available in Pakistan as well as in the world. Therefore, present study was carried out a) to record the disease incidence and b) to manage the infected crop through nutrients and composts.

\section{MATERIALS AND METHODS}

The trial was carried out at the research area of University College of Agriculture, University of Sargodha, Pakistan. The nurseries of four varieties (VRI-20, VRI-49, Nagina and Money maker) were raised in earthen pots having sandy loam soil added with one part of farm yard manure (FYM). The soil was sterilized with Formalin (1:340) prior filling the pots to inhibit the growth of soil borne plant pathogens. At 3-5 leaves stage tomato plants were transplanted into the field. Seed beds were prepared. The plant to plant distance of 9 inches and row to row 2 feet were maintained. All the recommended agronomic practices were carried out during the trial.

Disease Incidence and severity: On the basis of visual symptoms, disease incidence was calculated after the interval of fifteen (15) days as follows until two weeks before harvesting.

\section{RESULTS}

Incidence and disease severity of TLCV: The disease incidence was in the range of $57 \%$ to $70 \%$. The highest disease incidence was recorded in VRI-20 (70\%) followed by Nagina (66\%) and Money Maker (63\%). The least disease incidence $(57 \%)$ was recorded in VRI-49 (Table 1 ). The disease severity was recorded on the basis of disease rating scale where VRI-49 showed moderately resistant (MR) response while VRI-20 was highly 
susceptible (HS), Whereas Nagina and money maker were susceptible (S) against TLCV (Table 2).

Impact of treatments on disease severity: Application of the four treatments on Tomato varieties showed significant results. Those treatments suppress the progression in disease severity. Among all the treatments, compost (T2) was found to be the most significant in reducing the progression of disease severity. The effect of Nutrient Enriched Compost (T3) was at par with that of compost. The progression of TLCV disease severity for nutrients (T4) and control (T1) hardly had any difference among each other (Table 3). The statistical analysis also revealed that progression in TLCV disease severity was significantly reduced due to the application of compost $(44.02 \pm 3.26 \mathrm{c})$ as compared to control where the disease was progressing with the passage of time (55.38 $\pm 3.28 \mathrm{a})$. The effect of NEC and multi-nutrients was not significantly different among each other with standard deviations in mean values of $50.69 \pm 3.15 \mathrm{ab}$ and $54.16 \pm 2.63 \mathrm{~b}$ respectively. Nutrients showed the suppression of disease progression in three varieties (Money Maker, Nagina and VRI-20) which were susceptible. The least suppression in disease severity progression was found in moderately resistant variety VRI-49 (45.91 $\pm 3.18 c)$ (Table 3).

Table 1. Incidence of TLCV on four varieties/line of tomato

\begin{tabular}{lccc}
\hline Varieties & Total plants observed & Infected plants & Incidence (\%) \\
\hline VRI-49 & 120 & 69 & $57 \%$ \\
\hline VRI-20 & 120 & 84 & $70 \%$ \\
\hline Money Maker & 120 & 76 & $63 \%$ \\
\hline Nagina & 120 & 80 & $66 \%$ \\
\hline
\end{tabular}

Table 2. Incidence of TLCV on four varieties/lines of tomato

\begin{tabular}{lll}
\hline Varieties & Severity Index & Reaction \\
\hline VRI-49 & 2 & Moderately resistant (MR) \\
\hline VRI-20 & 4 & Highly Susceptible (HS) \\
\hline Money Maker & 3 & Susceptible (S) \\
\hline Nagina & 3 & Susceptible (S) \\
\hline
\end{tabular}

Table 3. Impact of different treatments/varieties on disease severity of TLCV on four tomato varieties/lines

\begin{tabular}{lrrrrr}
\hline \multirow{2}{*}{ Varieties } & \multicolumn{4}{c}{ Treatment } & \multirow{2}{*}{ Means \pm S.D } \\
\cline { 2 - 5 } & Control & Compost & NEC & Nutrients & \\
\hline Money Maker & 53.33 & 47.22 & 51.66 & 48.88 & $50.27 .16 \pm 3.06 \mathrm{~b}$ \\
\hline Nagina & 53.33 & 46.66 & 49.44 & 53.33 & $50.69 \pm 3.28 \mathrm{~b}$ \\
\hline VRI-49 & 45.88 & 35.55 & 46.66 & 55.55 & $45.91 \pm 3.18 \mathrm{c}$ \\
\hline VRI-20 & 69.00 & 46.66 & 55.00 & 58.88 & $57.47 \pm 2.88 \mathrm{a}$ \\
\hline & $55.38 \pm 3.28 \mathrm{a}$ & $44.02 \pm 3.26 \mathrm{c}$ & $50.69 \pm 3.15 \mathrm{ab}$ & $54.16 \pm 2.63 \mathrm{~b}$ & \\
\hline
\end{tabular}

Means within a column followed by the same letter are not significantly different according to Least Significant Difference Test $P=0.05$.

Relationship of environmental factors with TLCV disease severity: The environmental factors showed significant effect on TLCV in relation to all varieties. There was decrease in disease severity with the increase in maximum and minimum temperature. The linear regression model explained this relation, where the value of $\mathrm{R}$ is $-0.82^{* * *}$ for maximum temperature and $-0.77^{* * *}$ for minimum temperature. While rainfall showed a significant positive correlation with a value of $\mathrm{R} 0.34^{* * *}$. Relative humidity was positively correlated to TLCV disease severity (Figure 1). 


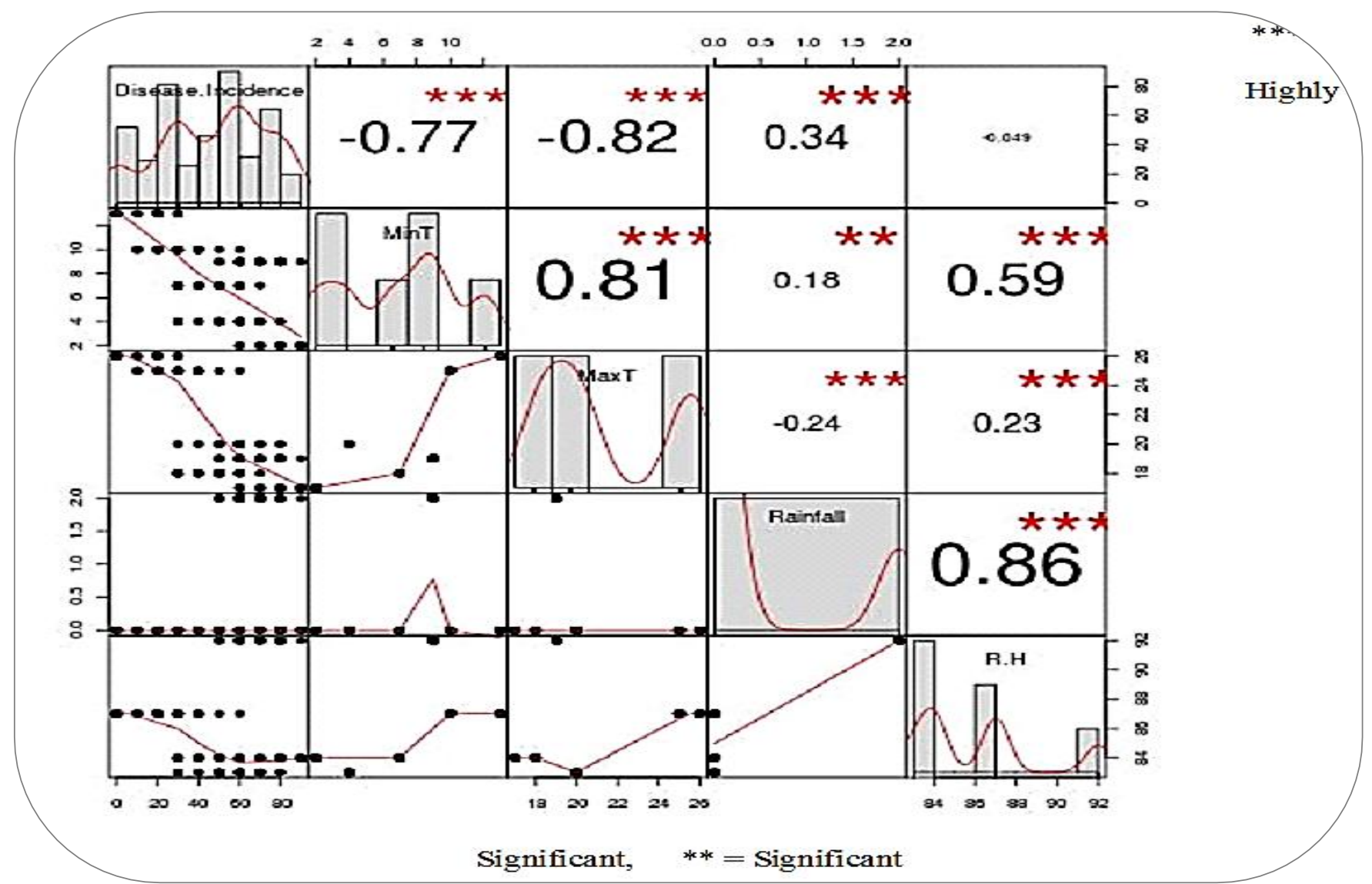

Figure 1. Relationship of environmental factors with disease severity

\section{DISCUSSION}

TLCV is one of the most prevalent virus diseases in the tomato field. It is an emerging Gemini virus in the tomato crop. The scarcity of information is available regarding incidence and management of TLCV. The incidence of virus disease was up to $70 \%$ in the field conditions. The treatments showed significant response towards TLCV and were able to suppress the disease severity in the field. Compost was the most effective with lowest disease severity value. The organic manures and composts have a direct effect on suppressing the disease by stimulating competing micro-organisms and also able to induce resistance in the plant against diseases (Shafique et al., 2016; Hoitink, 2006). In our findings, compost plays a vital role in suppressing TLCV and results were similar to previous findings in relation to suppress different diseases (Ali et al., 2014; Ghorbani et al., 2006). Compost and some other manure against chili diseases were applied to check the efficacy. Compost was able to reduce the disease incidence of, another virus, chili leaf curl as compared to control (Hassan et al., 2013). The application of compost against virus diseases has a significant impact. In our results, compost was also proved to be significant in reducing the progression in disease incidence as compared to control (Chandrasekaran, 2005; De et al., 2005). The application of potassium has also been used to reduce the whitefly population. It was observed that whitefly population decreased by the application of a high dose of potassium which ultimately responsible for the increase in cotton leaf curl disease severity (Hassan et al., 1993). Epidemiology also plays the vital role in spread and development of the disease. Therefore, progression in disease incidence was correlated with environmental factors like maximum temperature, minimum temperature, relative humidity and rainfall. The maximum and minimum temperature had positive correlation while relative humidity and rainfall had a negative correlation with the disease but in our results maximum and minimum temperature was negatively correlated and relative humidity is positively correlated. The impact of environmental factors on TLCV has not been studied extensively. OYVMV and whitefly population were correlated with environmental factors. 
There was positive correlation between humidity and minimum temperature, While, rainfall had negative correlation for tomato viruses that is contradicting to our results (Hassan et al., 1993). Negative correlation was found between maximum temperature and whitefly infestation in relation to viral disease. There was significant correlation between relative humidity and whitefly and disease severity. Our results were in accordance with Ali et al., (2005) who found the nonsignificant correlation between rainfall and okra yellow vein mosaic virus. The relative humidity supports the virus disease development. Our results were similar to previous research (Kadian, 1989). There was statistical significant correlation of environmental factors with Tomato mosaic virus (ToMV) during the screening of different tomato varieties ToMV. Our results in relation to environmental factors did not match except rainfall (Imran et al., 2013). According to them there was decrease in disease severity with the increase in rainfall. The contradiction in our results with previous trend is due to the application of treatments to manage the TLCV disease. The direct information for the management of TLCV is not available in literature so continuous trials in future to develop the epidemiological model are the aspect to be studied. As treatments had their effect on disease development so it is highly possible that progression in the disease severity in relation to environmental factors was altered in our trial as compared to previous trend found in literature, where they studied the environmental factors on the untreated crops. It is also therefore concluded that nutritional management of TLCV was not affected by environmental factors and non-chemicals/organic amendments should be encouraged to manage the diseases.

\section{REFERENCES}

Ali, S., M. A. Khan, A. Habib, S. Rasheed and Y. Iftikhar. 2005. Management of yellow vein mosaic disease of okra through pesticide/bio-pesticide and suitable cultivars. Intl. J. Agric. Biol. 07(1): 145-147.

Ali, S., M. A. Khan, M. A. Zeshan and M. Usman. 2014. Eco-friendly approaches for the management of okra yellow vein mosaic virus disease (OYVMVD) incidence. Pak. J. Phytopathol. 26(1): 113-116.

Antignus, Y., D. Nestel, S. Cohen and M. Lapidot. 2001. Ultraviolet-deficient greenhouse environment affects whitefly attraction and flightbehavior. Environ. Entomol. 30(2): 394-399.

Chakraborty, S., P. K. Pandey, M. K. Banerjee, G. Kalloo and C. M. Fauquet. 2003. Tomato leaf curl Gujarat virus, a new begomovirus species causing a severe leaf curl disease of tomato in Varanasi, India. Phytopathol. 93(12): 14851495.

Chandrasekaran, M. 2005. Symptomatology of chilli leaf curl. J. Ecotox. Environ. Monit. 15(4): 377380.

Chavan, A. K., R. S. Choudhary, R. B. Narwade and R. H. Autade. 2015. Identification of Tomato Leaf Curl Virus (ToLCV) Strain Causing ToLCV in Tomato and Chilli. Intl. J. Sci. Res. 4(8): 1713-1716.

De, B. K., A. K. Saha and P. S. Nath. 2005. Leaf curl virus disease incidence in chilli in the plains of West Bengal. Environ. Ecol. 23: 261-263.

Ghorbani, R., S. Wilcockson and C. Leifert. 2005. Alternative treatments for late blight control in organic potato: Antagonistic micro-organisms and compost extracts for activity against Phytophthora infestans. Potato Res. 48(3-4): 181-189.

Gottlieb, Y., E. Zchori-Fein, N. Mozes-Daube, S. Kontsedalov, M. Skaljac, M. Brumin and M. Ghanim. 2010. The transmission efficiency of tomato yellow leaf curl virus by the whitefly Bemisia tabaci is correlated with the presence of a specific symbiotic bacterium species. J. virol. 84(18): 9310-9317.

Hassan, M. R., I. Hossain, M. R. Islam and M. A. R. Khokon. 2013. Comparative Efficacy of Compost, Compost Tea, Poultry Litter and Bavistin in Controlling Diseases of Chili. Progress. Agric. 24(1-2): 39-44.

Hassan, S., M. Arif and T. Defoer. 1993. Preliminary studies on viral diseases of tomato in Malakand agency of North West Frontier Province. NWFP. Pakistan. Sarhad J. Agric. Pak.

Hoitink, H. 2006. Compost use for disease suppression. On Farm Composting Handbook http://plantpath. osu. edu/facultyandstaff/faculty-directory/hoitink-harry-aj.

Imran, M., M. A. Khan, M. Fiaz, M. Azeem and M. Mustafa. 2013. Influence of environmental conditions on tomato mosaic virus disease 
development under natural condition. Pak. J. Phytopathol. 25(2): 117-122.

Kadian, O. P. 1989. Effect of environment on incidence and development of leaf crinkle disease in urdbean. Indian Phytopathol. 42: 272.

Lapidot, M., M. Friedmann, M. Pilowsky, R. Ben-Joseph and S. Cohen. 2001. Effect of host plant resistance to Tomato yellow leaf curl virus (TYLCV) on virus acquisition and transmission by its whitefly vector. Phytopathol. 91(12): 1209-1213.

Maluta, N. K. P., E. Garzo, A. Moreno, J. R. S. Lopes and A. Fereres. 2014. Tomato yellow leaf curl virus benefits population growth of the Q Biotype of Bemisia tabaci (Gennadius) (Hemiptera: Aleyrodidae). Neotro. Entomol. 43(4): 385-392.

Mughal, S. M. 1985. Viral diseases of tomato and their control. Prog. Fmg. 6(2):20-23.

Polston, J. E. and M. Lapidot. 2007. Management of Tomato yellow leaf curl virus: US and Israel perspectives. In Tomato yellow leaf curl virus disease. Springer Netherlands. 251-262.

Raj, S. K., R. Singh, S. K. Pandey and B. P. Singh. 2005. Agrobacterium-mediated tomato transformation and regeneration of transgenic lines expressing Tomato leaf curl virus coat protein gene for resistance against TLCV infection. Curr. sci. 88(10): 1674-1679.

Rybicki, E. P. 2015. A Top Ten list for economically important plant viruses. Arch. Virol. 160(1): 1720.

Shafique, H. A., V. Sultana, S. Ehteshamul-Haque and M. Athar. 2016. Management of soil-borne diseases of organic vegetables. J. Pla. Prot. Res. 56(3): 221-230.

Sugano, J., M. Melzer, A. Pant, T. Radovich, S. Fukuda, S. Migita and J. Uyeda. 2011. Tomato Yellow Leaf Curl Virus-Resistant Varieties for Commercial Production. Plant Dis. 78. 